\title{
GZMB Gene
}

National Cancer Institute

\section{Source}

National Cancer Institute. GZMB Gene. NCI Thesaurus. Code C104263.

This gene plays a role in cell-mediated cytolysis. 